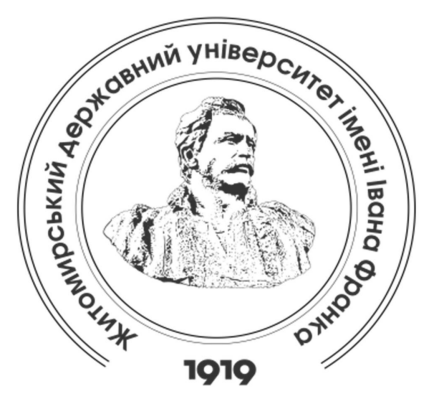

Zhytomyr Ivan Franko State University Journal. Pedagogical Sciences. Vol. 3 (102)

Вісник Житомирського державного університету імені Івана Франка. Педагогічні науки. Вип. 3 (102)

ISSN (Online): 2664-0155

UDC 378.147:37.015.31:376-054.62
DOI 10.35433/pedagogy.3(102).2020.45-55

\title{
SCIENTIFIC SELECTIVE AS A TYPE OF CREATIVE ACTIVITY IN SPIRITUAL AND INTELLECTUAL EDUCATION AND TRAINING OF STUDENTS
}

\author{
N. V. Kalashnik ${ }^{*}$, N. V. Logutina ${ }^{* *}$, M. M. Barus ${ }^{* * *}$
}

Topicality of the issues of education of foreign students in the higher medical educational institutions of Ukraine is growing, which is associated with the desire and ability of medical universities to strengthen and develop their economic basis.

The article presents the main forms of research work conducted by students within the research groups of the departments of Ukrainian Language Studies, Latin and Medical Terminology, for their experience provides an opportunity to form stable skills of independent research work, as well as to improve the quality of mastering internal medicine, and to develop creative and analytical thinking. This helps students to expand their worldview, develop the ability to apply theoretical knowledge and modern research methods in practice, which is of great importance for career guidance and for their further research work after graduation. Attention is paid to the relationships and mutual influences (psychotherapy) of culture and art, religion and science. One of the means of supporting the student in his/her spiritual orientation development is participation in amateur art contests, brain-rings, as well as conducting country studies, preparing speeches with interdisciplinary links, creating poster-based presentations for the day of embroidery, analyzing symbols of Ukraine, its holidays and traditions, etc. Reading the "Canon of Medical Science" by Abu Ibn Sina, we prove that it is necessary to be interested in the life, culture and science of the people who study in higher education, thus stimulating knowledge not only in medicine but also developing intellectual and creative skills of the future specialist.

\footnotetext{
${ }^{*}$ Candidate of Pedagogical Sciences (PhD in Pedagogy), Associate Professor

(National Pirogov Memorial Medical University, Vinnytsya)

kalashnuknatalia@gmail.com

ORCID: 0000-0001-5312-3280

${ }^{* *}$ Candidate of Pedagogical Sciences (PhD in Pedagogy), Educator

(National Pirogov Memorial Medical University, Vinnytsya)

natalia.logutina@gmail.com

ORCID: 0000-0003-1029-5247

${ }^{* * *}$ Candidate of Chemical Sciences (PhD in Chemistry), Associate Professor

(Bukovinian State Medical University, Chernivtsi)

barus.m@bsmu.edu.ua

ORCID: 0000-0001-9447-6170
} 
The article analyzes the results of Ukrainian Internal Medicine competitions for medical students. It has been proved that the competition contributes to the development of creative clinical thinking of students and involves not only the traditional theoretical knowledge and practical skills, but also the use of novel interactive computer technologies and visualizing techniques (photos and / or video protocols, video imaging, etc.).

Key words: higher education, future specialist, the student research group, independent research work, higher medical institutions, foreigh students, amateur arts, contests, independent research work.

\title{
НАУКОВИЙ ГУРТОК ЯК ВИД КРЕАТИВНОЇ ДІЯАЬНОСТЇ В ДУХОВНО- IНТЕАЕКТУАМЬНОМУ ВИХОВАННI ТА НАВЧАННІ СТУДЕНТСЬКОЇ МОАОДІ
}

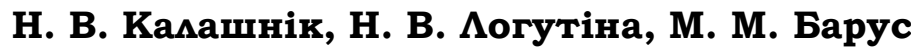

Актуальність проблеми навчання іноземних студентів у медичних закладах вищої освіти України зростає у зв'язку із збільшенням їх контингенту в останні роки, прагненням та можливостями закладів зміинювати свої економічні показники та гідно представляти себе на міжнародному рівні.

У статті представлено основні фрорми науково-дослідної роботи, до яких залучаються студенти-іноземиі в межах студентських наукових гуртків кафедр українознавства, латинської мови та медичної термінології. Активна спільна діяльність викладачів кафредр зі студентами - иленами гуртків надає їм можливість отримати стійкі навички самостійної науково-досліднииької роботи, підвищити якість засвоєння медииини, розвинути творче та аналітичне мислення, допомагає розширити світогляд, виробити вміння застосовувати теоретичні знання $і$ сучасні методи наукових досліджень на практииі. Отримані знання, вміння та навички вдосконалюють майстерність майбутніх фахівиів-медиків, сприяють розвитку профресійної компетентності, та у більшості випадків сприяють продовженню наукової роботи після закінчення закладу вищої освіти. Викладачами акиентуеться увага на міжкультурних взаємовідносинах та взаємовпливах, національних особливостях культури, мистеитва, релігії, науки різних народів.

Зазначено, ио одним із засобів підтримки студента в його духовній орієнтаиії є участь в художній самодіяльності, проведення країнознавчих брейн-рингів, виступів з використанням міжпредметних зв'язків, підготовка стендових доповідей до дня вишиванки, свята і традииї україниів, державні символи України, організаиія фрлешмобу "Я-українка!", "Спадок" тощо. На прикладі "Канону лікарської науки" Абу Ібн Сіни, демонструємо, шо необхідно цікавитись життям, культурою та наукою народів, представники яких навчаються у закладі вищої освіти, поглиблюючи иим пізнання не лише в галузі медииини, але й всебічно розвиваючи майбутніх фрахівиів медичної галузі, удосконалюючи їх інтелектуальні та твориі здібності.

Ключові слова: вища освіта, студенти-медики, підготовка іноземних студентів, студентський науковий гурток, самостійна наукова робота, форми науково-дослідної роботи, духовно-інтелектуальне виховання, творчий розвиток.

Introduction of the issue. There are certain changes in domestic and foreign experience of treating patients in the field of healthcare, which include the right to choose a qualified doctor and the availability of medical services despite the fact that they are expensive. In such circumstances, there are certain requirements for the identity of the doctor and his/her functional responsibilities. This presupposes the introduction of humanistic views into the educational process, which help treat the future medical worker as a free spiritual personality in need of selfdevelopment, as well as close attention 
is paid to each individual. Thus, only an educational institution with a high scientific and methodological level can ensure an effective educational process for foreign students, so that students from other countries, coming home, remember with gratitude Ukraine, where they were taught the medical profession. After graduating from higher educational establishment, the future specialist must be highly competitive in the labor market. Research work (RW) is one of the links in the formation of a quality level of education in all higher educational institutions of Ukraine (Universities), including higher medical schools. The main part of RW of students is one of the main components of professional training, which involves teaching methodology to students, including research methods, as well as systematic participation in research activities, application of technologies and creative skills in order to solve certain professional scientific problems. In Ukraine, students' RW is ensured by normative and legislative documents, namely by the Law of Ukraine "On Scientific and Scientific-Technical Activity" (2014) and the Law "On Higher Education" (2014).

The concept of students' research work includes two interrelated elements:

- teaching students elements of research, organization and methods of scientific creativity;

- practical research carried out by students under the guidance of an educator. Independent work of students is divided into educational and research-based, which is included in the educational process and is carried out during working hours, nevertheless, RW is usually performed in extracurricular time.

Students' research consists of the following types of work: a) work in scientific societies, student research groups (SRGs) and problem groups (PG) operating at the departments; b) participation in research work on scientific topics; c) speeches, reports and announcements at scientifictheoretical and scientific-practical conferences held at the educational institution(s); d) participation in intrauniversity, inter-university, regional events, which are conducted according to the Constitution of Ukraine, including current legislation and the Regulations of the Student Scientific Society of the University [1].

Current state of the issue of education of foreign students in the higher medical educational institutions of Ukraine is growing, which is due to the desire and ability of medical Universities to strengthen their economic conditions and development. Accumulated experience of the National Pirogov Memorial Medical University, which has been teaching foreign students for almost half a century, allows us to make some conclusions concerning the mentioned issues.

Aim of the research is to analyze and review the peculiarities of educational process in a higher educational institution (HEI), paying particular attention to the issues encountered by foreign students studying abroad, namely:

- a complex process of adaptation and accomodation in the new sociocultural environment;

- acquiration of skills of intercultural communication;

- learning the local language.

Outline of the unresolved issues brought up in the article. Based on the processed data, we note that there is a number of studies on the formation of professional competencies of future doctors, including professional speech competence intercultural (A. Vardanyan), competence of foreign students (N. Kalashnik, T. Philip), multicultural competence of medical students (A. Shcherbakova). However, there are not enough works in which the ways of formation of interpersonal 
competencies of future doctors of both domestic and foreign students would be revealed. In the article by L. Hepenko and L. Rybalko the idea of such a component of professional training of future doctors as intercultural education is viewed in a certain way.

It should be noted that the works of I. Voloshanska, A. LesnianskaDoshchak, S. Pilishek, Z. Halo, and O. Yuzvyak carry out similar content, which reveals the needs of intercultural education of young people in Germany, as well as the necessity for coexistence of people of different ethnic backgrounds, including those who study together.

Thus, the article by D. Danko and I. Kozubovska [6] substantiates the needs of forming the readiness of foreign students for intercultural communication; yet, education of foreign students has certain specific features and causes issues, such as language barrier, lack of awareness of patterns of formation of Ukrainian society. We support the opinion that students' readiness for intercultural communication correlates with such components as a positive attitude to cooperation and the formation of trustworthy cooperative relationships in the process of communicative interaction. Scientists G. Kardashevska and O. Movchan consider the need for the formation of intercultural tolerance as an important component of the professional development of the future physician. According to the researchers, intercultural tolerance should imply a corresponding attitude of the doctor to all types of people with whom they interact in professional communication. Differences in culture are not generalized in the rules and, therefore, in a "professional communication of a doctor cultural errors become especially important, for they can cause not only difficulties in communication, but also cause deterioration of the patient's condition, reducing the effectiveness of treatment" [4; 5: 41].
Results and discussion. One of the conditions for ensuring the effectiveness of the educational process is to take into account the peculiarities of the adaptation of foreign students to the socio-cultural environment of Ukraine. Success in obtaining higher education, employment, etc. depends on how foreign students adjust to new conditions, which are often unusual for them. National Pirogov Memorial Medical University occupies a worthy place among medical universities of Ukraine, which train specialists for different foreign countries.

The first thing that is required from students from other countries is the good command of Ukrainian language, for its importance for further study of foreigners in Ukraine is immence. Moreover, lack of proficiency in the Ukrainian language implies certain limitations on communication between foreigners and domestic students, for interaction outside the educational institution does not allow to study the rich historical and cultural heritage of the state [2].

Thus, language helps to form the personality of the future specialistforeigner as a member of a team; moreover, traditions that have developed in the school, ethical education, including the organization of student leisure: celebrations for Independence Day, national holidays of the countries from which students came to study, festivals of national creativity student days and dedications to students, which are eagerly awaited by both students and teachers. The official ceremonies of taking the Hippocratic oath, the oath of a doctor and a graduate ceremony are the examples of good traditions. This relationship between the creative development of the student and the provision of the environment of high spirituality of the educational institution, contributes to the creation of a friendly psychological climate in the educational process, which is 
designed to encourage students' desire to create something new.

Attention is paid to the relationships and mutual influences (psychotherapy) of culture and art, religion, and science. Another means of supporting the student in his/her spiritual orientation is to participate in amateur art, conducting local history brain-rings, brainstorming, various national holidays, open demonstration lectures, speeches with the use of interdisciplinary links, preparation and traditions of Ukrainians, state symbols of Ukraine, organization of a flash mob "I am Ukrainian!" , photo flash mob "Ethno fashion", "Beautiful Ukrainian", "Heritage of the Nation", "Medicine in the works of Shevchenko", "Stus readings", Shakespeare's Poetry Days (in the original language), interdepartmental associations with the development of such research topics as: "Medicine and Art", "Medicine in Painting", "Literature and Medicine", "Music as an Element of Psychotherapy", "Latin and its application in medicine, in the Ukrainian language", "The role of Latin in the formation of Latin terminology", "Historical role of Latin as an international language of science", "Latinisms on Ukrainian soil" etc. Reading the "Canon of Medical Science" by Abu Ibn Sina, we prove that it is necessary to be interested in the life, culture and science of the peoples whose representatives study at our university, thus stimulating knowledge not only in medicine but also developing intellectual and creative skills specialist.

As for the formation of a foreign student as a future clinician, an important aspect is direct communication with the patient, which gives the opportunity to correctly formulate the diagnosis, as well as to develop further tactical and therapeutic measures. In order to avoid the language barrier in communication between the student and the patient at the Department of Ukrainian Studies, additional classes were introduced, and a schedule of shifts is created for working out some sections of the curriculum. The quality process of language and professional training is provided by experienced teachers. The main purpose of education at our university is to train highly qualified specialists.

Evidence of this is the fact that more and more foreign students, having completed pre-university and university selectives continue their postgraduate education in our higher education institution.

The priority for the university remains: to increase international influence through the spread of Ukrainian culture, language and training of the intellectual elite for foreign countries, for our students in the future will represent the university all over the international educational arena.

Foreign student youth differs in religion, ethnic composition, language, culture, but all of them (us) are united by one the desire to learn. And the country they have chosen to realize their desire is really our country Ukraine.

What do students who have chosen our country to study know about Ukraine? As a rule, almost nothing. They do not know the history of Ukraine at all. At best, they associate our culture only with the names of some pop singers, football players or boxers, with the names of some movies and cartoons that they managed to watch in their homeland. How do foreigners imagine our country before coming to us? Frosty, snowy and incomprehensible.

The problems that foreign students face in the educational process are successfully solved with the help of teachers. It is much more difficult to solve the problem of "deficit" of communication with Ukrainians, speakers of our language and culture, 
the need for which is felt by all foreign students. They reach out to their peers, they lack communication. Our task is to help expand the circle of communication with peers, including Ukrainian students [3].

Thus, at the Department of Ukrainian language Studies there is a student research group for foreign students "Desiderius Erasmus", organized under the leadership of Associate Professor of Ukrainian Studies Natalia Kalashnik. The circle is named after the prominent Dutch scientist of the XV century, humanist and theologian Erasmus of Rotterdam, who traveled extensively in Europe, studied and worked at various universities. The main purpose of the circle is in-depth study of the subject and the basics of scientific research. A similar group on the basics of Latin terminology was organized under the leadership of NV Logutina. The purpose of which is cooperation, exchange of scientific research, discussions and scientific research.

The purpose of the student scientific class is determined by:

1. Identifying the most capable and talented students prone to research.
2. Deepening of research on the issues of scientific activity of the departments with the participation of students.

3. Acquisition of skills to perform scientific work.

4. Involvement of gifted students in further research activities

The priority tasks of the student scientific class are:

1. Involvement of students who are interested in research work.

2. Organization of research work of students.

3. In-depth study of the chosen discipline by students.

Execution of scientific work also provides the solution of such basic tasks as:

a) the formation of a scientific worldview, mastering the methodology and methods of scientific research;

b) development of creative thinking and individual abilities of students in solving practical problems;

c) development of initiative, ability to apply theoretical knowledge in practice;

d) expanding the theoretical horizons and scientific erudition of the future specialist.

The extracurricular-activity syllabus for fellows of the Latin language society

\begin{tabular}{|c|c|l|}
\hline No & Date & \multicolumn{1}{c|}{ Subject } \\
\hline 1. & 26.09 .2019 & $\begin{array}{l}\text { Organization meeting. Discussing and approvment of } \\
\text { main tasks and spheres of Latin curriculum }\end{array}$ \\
\hline 2. & 17.10 .2019 & $\begin{array}{l}\text { Classical languages on the basis of international medical } \\
\text { terminology. Lexico-semantic groups of medical terms. } \\
\text { Lexico-semantic fields in the Latin terminology }\end{array}$ \\
\hline 3. & 21.11 .2019 & $\begin{array}{l}\text { Professional medical phraseology. Linguocultural aspect } \\
\text { of medical opera written in classical languages }\end{array}$ \\
\hline 4. & 12.12 .2019 & $\begin{array}{l}\text { Formation, standartization and dynamics of medical } \\
\text { terminologies. Medical terminology: nomenclature and } \\
\text { inernational standarts }\end{array}$ \\
\hline 5. & 20.02 .2020 & $\begin{array}{l}\text { Origins of terminological word-building. Semantics. } \\
\text { Etymology. Systematization. Vocabulary. Pharmaceutical } \\
\text { terminology. International chemical nomenclature. } \\
\text { Terminological word-building }\end{array}$ \\
\hline 6. & 19.03 .2020 & $\begin{array}{l}\text { The acient Greek language. Phonetics and morphology } \\
\text { fundamentals. Etymological and semantic analysis of } \\
\text { medical terms.The present state of Latin and Acient Greek }\end{array}$ \\
\hline
\end{tabular}




\begin{tabular}{|c|c|l|}
\hline No & Date & \multicolumn{1}{|c|}{ Subject } \\
\hline 7. & 02.04 .2020 & $\begin{array}{l}\text { Clinical terminology. Translation peculiarities. } \\
\text { International standarts and taxonomy of clinical terms } \\
\text { and diagnosies }\end{array}$ \\
\hline 8. & 09.04 .2020 & $\begin{array}{l}\text { Final meeting. Consideration and approvment of working } \\
\text { results of the Latin language society for 2020-2021 }\end{array}$ \\
\hline
\end{tabular}

Thus, all this allows to choose those students who have the ability and motivation to improve their medical skills, the development of their organizational skills.

The main principles of scientific work are: creative approach, planning, dynamism, self-organization, critical and self-critical, practicality; The main qualities of a scientist are: professional knowledge, diligence, curiosity, observation, initiative, sense of the new, interest in the case, punctuality, diligence, responsibility and reliability, organizational skills, sociability, friendliness. There is always a coffee break between breakout sessions (or after) where young scientists can share their impressions, plans and ideas for future research.

Within the framework of the section meeting of the Department of Ukrainian language Studies, author's exhibitions of group members and all those wishing to join the educational activities of our actives take place. Student scientific group of the Department of Ukrainian Studies "DESIDERIUS ERASMUS" conducts educational work among student youth, giving reports on disease prevention, promotion of healthy lifestyles and others, participating in various meetings, presentations, campaigns, promotions, film lectures, excursions and exhibitions.

In order for our students not to lose touch with each other, a student research group for foreigners was created, where foreign youth have the opportunity to communicate with each other, hold joint events, including interdepartmental events with the section of Latin and medical terminology. They live in Ukraine and they are not indifferent to the history of Ukraine, culture, our language, customs and traditions of the Ukrainian people, are interested in indepth study of medicine.

Students began to take an active part with reports and announcements at scientific-theoretical and scientificpractical conferences held at the educational institution, participation in intra-university and inter-university, competitions for the best scientific work or poster presentation, with involvement in online conferences, medical exhibitions, competitions , flash mobs, newspapers, poster reports on the field of local lore and participation in interuniversity events in which there is a growing interest. Indepth study of local lore material increases the motivation to learn the language. The student who prepares for the speech spends his personal time, is responsible for himself, only the quality of presentation of the received information depends on him, thus developing in himself important skills of the future doctor-researcher.

Today, scientists' attention to the relationship between the creative development of the student's personality and the provision of an atmosphere of high spirituality of the educational institution, which encourages young people to imitate and create! Participation of student youth in a scientific circle is another means of personalization of education and support of the student's personality in its spiritual orientation, because a person who is interested in living cannot be indifferent! The efforts of our circle were aimed at forming a new personality of a doctor-thinker, 
intellectual, a person with a dominant national worldview, with a cultural and educational orientation.

The urgent task of participating in the scientific class is the development of the ability to learn independently all life, the need to replenish knowledge through self-education. In the students' scientific class there is an opportunity to gain stable skills of independent research work, to improve the quality of mastering internal medicine, to master the skills of professional speech, to develop creative and analytical thinking. Outstanding clinician Matthew Yakovl. Mudrov rightly argued that in the art of medicine there are no doctors who have completed their science. This is achieved by improving independent work, which activates the cognitive ability of students, stimulates scientific research.

The only wish is to involve teachers who work with foreign students in extracurricular activities: scientific and cultural activities (writing reports, articles, studying the experience of teachers-innovators, testing, questionnaires, pedagogical observation). The supervisor helps to determine the topic of research, the direction of scientific research, and thus there is cooperation and mutual understanding. Thanks to such cooperation of the teacher-student the cultural level raises.

According to the Resolution of the Presidium of the Academy of Sciences of Ukraine "On the development of science and transformation of society: a concept for Ukraine", the main goal of scientific, technical and innovative policy of the education system is: training, scientific and scientificpedagogical staff educational, scientific, technical and innovative potential for economic development [4]. This can be achieved by creating a professional and creative environment for student learning. One of the effective forms of work is a scientific circle for the student community, focused primarily on creative self-development and selfimprovement of the future. that the student research group is the first step in the transformation of an ordinary student into an inquisitive, erudite, skilled student, then - into a good specialist, professional, teacher, researcher. In the format of a circle, students carry out research work, which in junior courses contributes to the organization of educational and cognitive activities.

The leading tasks of such classes are considered by scientists: education of physically and morally healthy person; assimilation of moral values, ideals, cultural traditions, ethical norms; formation of aesthetic tastes;

The main tasks of our group are as follows: - assistance in the formation of skills and abilities to apply the acquired knowledge in creative practical activities (writing reports, articles, studying the experience of teachersinnovators, testing, questionnaires, pedagogical observation during pedagogical practice); - development of creative thinking of students, their cognitive activity, independence of judgments, needs and ability to independently enrich their knowledge and master the skills of creative activity; - stimulating interest in the achievements of domestic and foreign education; - formation of a value attitude to the knowledge they master. First of all, our research group is designed for students in grades $1-3$, but the tasks for different courses are different. Thus, first- and second-year students get acquainted with the elements of scientific research, acquire skills of independent work on in-depth study of certain scientific problems. which are held in the form of abstracting; Senior students are involved directly in research work.

Well-known in medicine saying is: "Salus aergoti suprema lex" ("The good of the patient - the supreme law"). before life does not disappear as long as there are people who profess love! His 
words: Man must fight, fight evil, and not sit idly by, waiting for divine intervention "best resonate with the fourth point of the Hippocratic oath; "I swear! Never, under any circumstances, apply medical knowledge to the detriment of a person!" Thus, the formation of a doctor in the university begins with the solemn ritual of "dedication to students", continues in the scientific search in the circle, and ends with the acceptance of the solemn oath of the graduate.

The results of the student scientific circle are:

1. Identifying the most capable and talented students prone to research.

2. Deepening of research on the issues of scientific activity of the departments with the participation of students.

3. Acquisition of skills to perform scientific work.

4. Involvement of gifted students in further research activities at the postgraduate stage of study.

The main tasks of the student research group and problem group are:

1. Involvement of students who are interested in research work.

2. Organization of research work of students.

3. In-depth study of the chosen discipline by students.

Thus, Ukraine allows you to choose those students who have the ability and motivation to improve their medical skills, the development of their organizational talents, offers students various methods of improving these qualities, namely regular clinical tours with experienced teachers, duty in the clinic, preparation and participation in competitions, participation in various conferences, presentations, trips to other cities and countries to study. The general management of the CIS work is carried out by the head of the department, and the current work is carried out by the scientific director of the University. These meetings are held twice a month, with each subsequent meeting held by a different teacher of the department. The topic of this kind of class is chosen by the curator, it allows students to listen, study, get state-of-the-art information on this topic. Therefore, before the beginning of the academic year, an annual work plan of the University is drawn up, in which the topics, the curator of the meeting (teacher who has a degree of candidate of science or associate professor), forms of work of students are indicated. Forms of organizing the work of group members are a seminar, scientific debates, a workshop, individual work, etc. Lesson materials are developed by curators, guided by the principle of unity of theory and practice. At the beginning of the meeting the teacher acquaints the students with the chosen topic in the form of a mini-lecture, formulates the purpose and lesson plan of the circle, then tells about new scientific aspects of the chosen problem. The second stage involves students: one or two students (who received the task the day before to work on the most important new achievements in diagnosis or treatment on the topic) in the form of a presentation or abstract share their views on this topic. A student who prepares for a group spends his personal time, is responsible for himself, only the quality of presentation of the information depends on him, thus developing important qualities for the future research doctor - creative thinking, responsibility and ability to defend their position. The last stage of each meeting is a lively discussion, during which the group members actively discuss current aspects of the topics discussed. Master classes are a new form of conducting the CIS. Unusual format, the ability to diagnose, plan a test plan and prescribe treatment for additional laboratory and functional indicators (supervisor at the request of the student provides all necessary data) help to combine theoretical knowledge and practical 
skills, increase motivation to learn. At his own request, the student performs his own research under the guidance of a teacher, the results of which are reported at the section of internal medicine of the annual International Medical and Pharmaceutical Congress of students and young scientists.

\section{Conclusions and research} perspectives. Student scientific selectives as a kind of independent work form the skills of public speaking, as well as the ability to reason logically. The student-student learning model enables them to participate in discussions, substantiate their points of view on a problem, answer the corresponding questions. Over the past five years, the results of scientific research have been reflected in publications in various journals, collections of scientific papers of students and young scientists. Achieving such high victories supports the student's desire to pursue science in the future and to link his/her further medical work with scientific activity at the university. An important aspect of becoming a doctor is mastering tolerance and mutual respect. Therefore, the teaching staff of the department pays much attention to the education of students in the spirit of mutual understanding and harmony between peoples, nationalities, religious groups, which can be clearly seen in the work of Ukraine. Teachers adhere to pedagogical ethics and morals, respect the dignity of students, set a personal example of the principles of universal morality: humanism, truth, justice, patriotism, devotion to their homeland, the medical profession. At the scientific meeting, students are instilled with the deontological principles of the medical profession - proper compassion for the patient and his relatives, providing them with information about the main or side effects of the drug, the consequences of safe and uncontrolled self-medication. The teacher emphasizes that a friendly attitude to the patient, a reassuring word from a doctor or psychologist, reassuring friendly sound information is a powerful means of mobilizing the body's defenses for recovery. The long-term experience of the department shows that students-students master theoretical knowledge, practical skills and professional skills better than those who do not participate in student research clubs.

1. Student scientific selectives help to develop creative and analytical thinking, expand the worldview of the student-circle, to develop the ability to apply theoretical knowledge and modern methods in practice.

2. The experience of the Department of Internal Medicine, Clinical Pharmacology and Occupational Diseases provides students with the opportunity to gain stable skills of independent research work, to improve the quality of knowledge acquisition in the field of internal medicine.

3. Students of the scientific class can deepen their knowledge in their chosen field of medical science, gain the necessary skills, which is of great importance for the further choice of the specialty of a doctor and for further scientific work of students after graduation.

\section{REFERENCES (TRANSLATED \& TRANSLITERATED)}

1. Denina, R.V. (2015). Students `kyy naukovyy hurtok: udoskonalennia profesiynykh navykiv [Student scientific circle: improvement of professional skills]. Bukovyns 'kyy medychnyy visnyk - Bukovynian Medical Bulletin, vol. 19, № 3 (75), 282-284 [in Ukrainian].

2. Zakon Ukrainy "Pro vyshchu osvitu" № 1556-VII vid 01.07.2014 [Law of Ukraine "On Higher Education" № 1556-VII of 01.07.2014]. zakon.rada.gov.ua. Retrieved from http: / / zakon.rada.gov.ua/laws/show/ 1 556-18 [in Ukrainian]. 
3. Kalashnik, N.V. (2019). Integration of foreign students into ukrain's culture. Scientific Research Priorities 2019: theoretical and practical value the IV International Scientific and Practical Conference: theoretical and practical value. Dariusz Woźniak (Ed.). Poland. Retrieved from https://bit-ly.ru/XYiww [in English].

4. Kalashnik, N.V.

(2016). Osoblyvosti osvitn'o-vykhovnoyi roboty $z$ inozemnymy studentamy u vyshchykh medychnykh navchal'nykh zakladakh Ukrayiny [Particularities of the cultural and educational work with the foreighn students in the higher medical institutions of Ukraine]. Visnyk Zhytomyrskoho derzhavnoho universytetu imeni Ivana Franka. Pedahohichni nauky - Zhytomyr Ivan Franko State University Journal. Pedagogical Sciences. Zhytomyr: Vyd-vo ZhDU im. I. Franka, vyp. 1 (83), 60-66 [in Ukrainian].

$$
\text { 5. Mynbaeva, A.K., }
$$

Sadvokasova, Z.M.

Innovatsionnyye metody obucheniya, ili kak interesno prepodavat': uchebnoye posobiye [Innovative teaching methods, or how interesting to teach: a textbook] (4th ed., ext.). Almaty: DOIVA [in Russian].

6. Pro rozvytok nauky ta transformatsiyu suspil'stva: kontseptsiya dlya Ukrayiny / Postanova prezydiyi Akademiyi nauk Ukrayiny. № 151 vid 03.06.1992 [On the development of science and transformation of society: a concept for Ukraine / Resolution of the Presidium of the Academy of Sciences of Ukraine. № 151 dated 03.06.1992]. www.uazakon.com. Retrieved from http://www.uazakon.com/documents [in Ukrainian].

7. Chornovol-Tkachenko, O.O. (2009). Naukovo-doslidnyts'ka diyal'nist' studentiv u VNZ Ukrayiny: zmist ta zavdannya [Research activity of students in Ukrainian universities: content and tasks]. Visnyk Kharkivs'koho natsional'noho universytetu imeni V.N. Karazina. Seriya "Romano-hermans'ka filolohiya. Metodyka vykladannya inozemnykh mov" - The Journal of V.N. Karazin isperivarkiv National University. Series: Foreign Philology. Methods of Foreign Language Teaching, № 866, 194-200 [in Ukrainian].

Received: August 28, 2020

Accepted: October 01, 2020 